\title{
Carbohydrate Metabolism of Staphylococcus aureus
}

\author{
By K. C. STRASTERS AND K. C. WINKLER \\ Laboratory of Microbiology, State University, Utrecht, Netherlands
}

(Received 11 March 1963)

\begin{abstract}
SUMMARY
The experiments described establish the importance of the pentose cycle in carbohydrate breakdown by Staphylococcus aureus. No EntnerDoudoroff pathway was found. Another feature is the extensive glucose effect: growth in glucose enhanced glycolysis suppressed the Krebs cycle, decreased the activity of the pentose cycle and suppressed the formation of many enzymes. Even the oxidation of pyruvic acid was decreased in glucose-grown organisms. The decrease of oxidative activity affected the cytochromes. The main products of carbohydrate oxidation were acetic acid and carbon dioxide. The accumulation of acetic acid indicated that the link between pyruvic acid and the citric acid cycle was weak.
\end{abstract}

\section{INTRODUCTION}

It is generally assumed that Staphylococcus aureus metabolizes glucose by glycolysis and subsequent oxidation of pyruvic acid (Elek, 1959). The breakdown of pyruvic acid has been studied by various authors but our knowledge about alternative pathways of glucose breakdown is scanty. Hancock (1960a) and Das \& Chatterjee (1962) obtained indications that a pentose cycle is present; Fusillo \& Weiss (1958) suggested a relation between the pattern of carbohydrate breakdown and resistance to antibiotics. Since there is a complete pentose cycle in Sarcina lutea (Dawes \& Holms, 1958a) a detailed study of the carbohydrate metabolism of $\boldsymbol{S}$. aureus seemed worthwhile. Five strains of $\boldsymbol{S}$. aureus of different phage groups were used, one strain being studied in more detail. By Warburg experiments, enzyme studies with cell-free extracts and experiments with radioactive substrates, a general picture of the carbohydrate metabolism of $S$. aureus was obtained.

\section{METHODS}

Abbreviations. The following abbreviations are used: B-cocci, cocci grown in broth; G-cocci, cocci grown in broth + glucose; G-6-P, glucose-6-phosphate; 6-P-G, 6-phosphogluconic acid; F-1,6-P, fructose-1,6-diphosphate; Gald-3-P, glyceraldehyde-3-phosphate; R-5-P, ribose-5-phosphate; GSH, reduced glutathione; NAD, nicotinamide-adenine-dinucleotide (DPN); NADH, the reduced form of NAD; NADP, nicotinamide-adenine-dinucleotide phosphate (TPN); NADPH, the reduced form of NADP; PMS, phenazine methosulphate; TCA, trichloroacetic acid.

The strains of Staphylocococcus aureus used were five propagating strains from the International Phage Typing System: 3 4 , 70, 77, 80, $187 \mathrm{~N}$ with NCTC nos. 8319, 8352, 8356, 9789 and 9753 , respectively. Strains of staphylococci were kept in stock as stab cultures in nutrient agar at $4^{\circ}$. After plating on blood agar single colonies were 
inoculated to agar slopes which were used as working cultures for one week. Bacto nutrient broth ( $8 \mathrm{~g} . / 1.0 \cdot 7 \% \mathrm{NaCl}$ solution) was used as liquid medium. Conventional Warburg techniques were used. Suspensions of logarithmic-phase cocci were prepared from $400 \mathrm{ml}$. broth cultures inoculated with $0.25 \mathrm{ml} .18 \mathrm{hr}$. broth culture and incubated at $37^{\circ}$ on a shaker until a standard turbidity $(80 \%$ absorbed light in a Moll extinctometer) was obtained. The cocci were centrifuged down, washed twice in phosphate buffer ( $\mathrm{pH} \mathrm{6.8)}$ ) and re-suspended in buffer to obtain a 40 -fold concentration (checked by turbidity). The quantity of cocci used in each Warburg experiment (as mg. dry weight) is indicated in the text.

Glucose was determined as described by Newburgh \& Cheldelin (1955), ribose according to Mejbaum (1939) and pyruvic acid by the method of Friedemann \& Haugen (1943) with xylene for the extraction. Acetic acid was determined as described by Rose, Grunberg-Manago, Korey \& Ochoa (1954), acetylmethylcarbinol by the method of Westerfeld (1945), lactic acid by the method of Barker \& Summerson (1941) and D (-)-lactic acid according to van den Hamer \& Elias (1958).

For the preparation of cell-free extracts, suspensions of cocci were obtained as described. The cocci were washed twice in $0.85 \% \mathrm{NaCl}$ solution and suspended in 0.01 M-phosphate buffer ( $\mathrm{pH} \mathrm{7 \cdot 0)}$. A suspension (15 mg. dry weight $/ \mathrm{ml}$.) was mixed with twice its volume of ballotini (no. 11) and treated for $15 \mathrm{~min}$. in a Mickle disintegrator at $4^{\circ}$ (Hancock, $1960 \mathrm{~b}$ ). The mixture was freed from ballotini by centrifuging in a linen bag. The fluid obtained was centrifuged for $30 \mathrm{~min}$. at $5000 \mathrm{~g}$. The supernatant fluid was used as cell-free extract; it contained about $10 \mathrm{mg}$. protein $/ \mathrm{ml}$. Details about the determination of enzymes are given in the text and in Table 5.

For incubation with radioactive substrates Warburg vessels closed with a rubber stopper were used. The same conditions were used as in the determination of oxygen uptake. The vessels contained equiv. $4 \mathrm{mg}$. dry wt. cocci. After incubation for $2.5 \mathrm{hr}$. at $37^{\circ}, 0.1 \mathrm{ml}$. of a solution of $\mathrm{NaHCO}_{3}(106 \mathrm{mg} . / \mathrm{ml}$. $)$ was added to the alkali in the centre well. The carbonate was precipitated as $\mathrm{BaCO}_{3}$ for the determination of radioactivity.

One ml. of the coccal suspension was filtered through a Millipore filter (type DA), and the cocci washed 3 times with phosphate buffer.

After adding non-radioactive glucose, filtrate and wash-waters were oxidized with $\mathrm{K}_{2} \mathrm{~S}_{2} \mathrm{O}_{8}$ (Aronoff, 1960) and the $\mathrm{CO}_{2}$ was collected as $\mathrm{BaCO}_{3}$. The $\mathrm{BaCO}_{3}$ was handled as described by Bosch (1955) and the radioactivity was determined on a layer of infinite thickness, using an end-window GM tube.

The cocci on the filter were dried with an infrared lamp and the radioactivity measured directly. It was shown in separate experiments that there was a constant ratio between the radioactivity of the cocci as measured directly and the activity of the $\mathrm{BaCO}_{3}$ formed from the cocci by oxidation. All activities are thus presented as total activity in cpm, measured on $\mathrm{BaCO}_{3}$.

The sum of the activities found in $\mathrm{CO}_{2}$, filtrate and cocci gave the recovery. There was a systematic loss of radio-activity by peptization of some $\mathrm{BaCO}_{3}$. Therefore the activities are expressed as \% of recovery. When not all the substrate was used by the cocci the values were corrected for unused substrate. 


\section{RESULTS}

Preliminary experiments. To obtain a first impression of the metabolic possibilities, the oxidation of glucose, gluconate, ribose, succinate and lactate by the five strains was studied by using suspensions of cocci grown in broth (B-cocci) and in broth $+\mathbf{0 . 1} \%$ glucose (G-cocci). The results are given in Table $\mathbf{1}$; a representative experiment is shown in Fig. $1 a, b$. The ready oxidation of the five substrates by B-cocci of all five strains seems to indicate that a pentose cycle as well as a citric acid cycle is present. It is however remarkable that the oxidation of the intermediates of the pentose cycle (ribose, gluconate) and of the citric acid cycle (succinate) were nearly completely suppressed in G-cocci.

Table 1. Oxidations by resting organisms of five strains of Staphylococcus aureus

Warburg vessels contained equiv. $15 \mathrm{mg}$. dry wt. organism, $0.5 \mathrm{ml}$. $0 \cdot 2$ m-potassium phosphate buffer ( $\mathrm{pH} 6 \cdot 8$ ); $10 \mu$ mole substrate were added from side-arm, total volume $\mathbf{2 . 4} \mathrm{ml}$. The centre well contained $0.1 \mathrm{ml} .20 \% \mathrm{KOH}$; gas phase was air. All data are presented after subtraction of endogenous respiration. The initial rate of oxygen uptake is given in $\mu$ mole $\mathrm{O}_{2} / \mathrm{hr}$. An asterisk * indicates that this rate was observed after an induction time. The total amount of oxygen used for the oxidation of $10 \mu$ mole substrate was recorded after $3 \mathrm{hr}$. Cont. means that the oxidation after $3 \mathrm{hr}$. was still going on; 0 that there is no oxidation at all.

\begin{tabular}{|c|c|c|c|c|c|c|c|c|c|c|}
\hline & & h-gro & $\begin{array}{l}\text { Wh sta } \\
\text { strain }\end{array}$ & hyloce & & Glu & cose-gr & $\begin{array}{l}\text { wn st } \\
\text { strain }\end{array}$ & hyyl & occi \\
\hline & $3 \mathrm{~A}$ & 70 & 77 & 80 & $187 \mathrm{~N}$ & $\mathbf{3 A}$ & 70 & 77 & 80 & $187 \mathrm{~N}$ \\
\hline G & & & & nitial & uptake & $\mathrm{O}_{2}(\mu \mathrm{n}$ & oole/hr & & & \\
\hline Endogenous & 5 & 5 & 4 & 7 & 8 & 3 & $\mathbf{1}$ & $\mathbf{2}$ & 2 & 1 \\
\hline Glucose & 46 & 43 & 49 & 47 & 35 & 57 & 42 & 50 & 50 & 40 \\
\hline Gluconate & 22 & $13 *$ & $17 *$ & $20 *$ & $\mathbf{5}$ & $\mathbf{1}$ & $\mathbf{1}$ & 2 & $\mathbf{0}$ & 0 \\
\hline Ribose & 12 & $8 *$ & 3 & $13^{*}$ & 5 & $\mathbf{1}$ & $\mathbf{0}$ & 2 & 1 & 0 \\
\hline Succinate & $22^{*}$ & 10 & 4 & $17 *$ & 18 & 0 & 0 & I & 0 & 0 \\
\hline Lactate & $\mathbf{3 4}$ & $\mathbf{2 4}$ & 26 & 27 & 21 & $\mathbf{3}$ & $\mathbf{5}$ & 8 & 24. & 11 \\
\hline Acetate & 0 & 0 & 0 & $\mathbf{0}$ & 0 & 0 & 0 & $\mathbf{0}$ & $\mathbf{0}$ & 0 \\
\hline & & & & umole & $\mathrm{O}_{2} / 10 \mathrm{r}$ & tole su & bstrate & & & \\
\hline Glucose & 29 & 21 & 27 & 20 & 22 & 21 & 18 & 21 & 21 & 20 \\
\hline Gluconate & 45 & 31 & 30 & 31 & Cont. & Cont. & Cont. & Cont. & $\mathbf{0}$ & o \\
\hline Ribose & 25 & 22 & Cont. & 27 & Cont. & Cont. & 0 & 0 & 0 & $\mathbf{0}$ \\
\hline Succinate & 36 & 33 & Cont. & Cont. & Cont. & 0 & 0 & Cont. & 0 & 0 \\
\hline Lactate & 19 & 19 & 13 & 15 & 25 & 10 & 8 & 10 & 10 & 10 \\
\hline Acetate & 0 & 0 & o & 0 & 0 & 0 & 0 & $\mathbf{0}$ & o & 0 \\
\hline
\end{tabular}

During the preparation of this paper Collins \& Lascelles (1962) published analogous results, at least with regard to the suppression of oxidations of the intermediates of the citric acid cycle in glucose-grown Staphylococcus aureus. The dependency of oxidative possibilities on growth conditions thus required further study. Strain 3A was used for these experiments.

Citric acid cycle. Intermediates of the citric acid cycle were readily oxidized by B-cocci of strain $3 \mathrm{~A}$ (Table 2 ). With G-cocci these substrates were not oxidized at all or only at an extremely low rate.

In cell-free extracts of B-cocci succinic dehydrogenase (Fig. 2) and malic dehydrogenase were found. Fumarase was shown by measuring the disappearance of the 


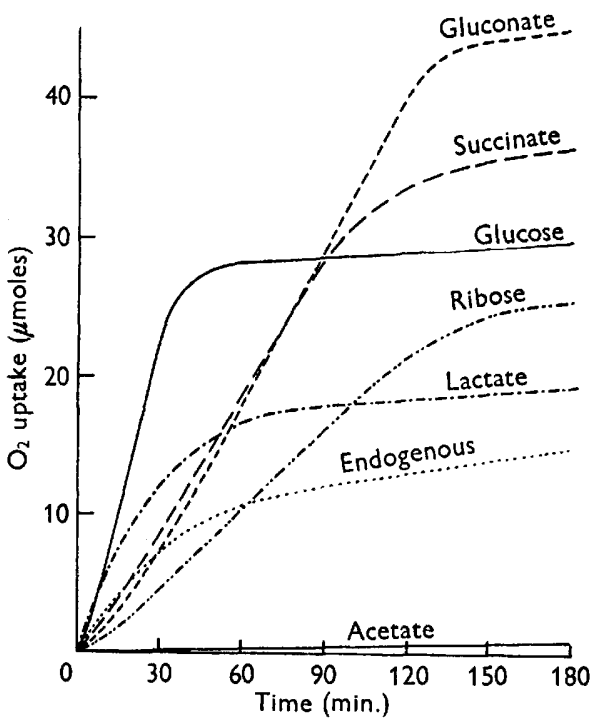

Fig. $1 a$

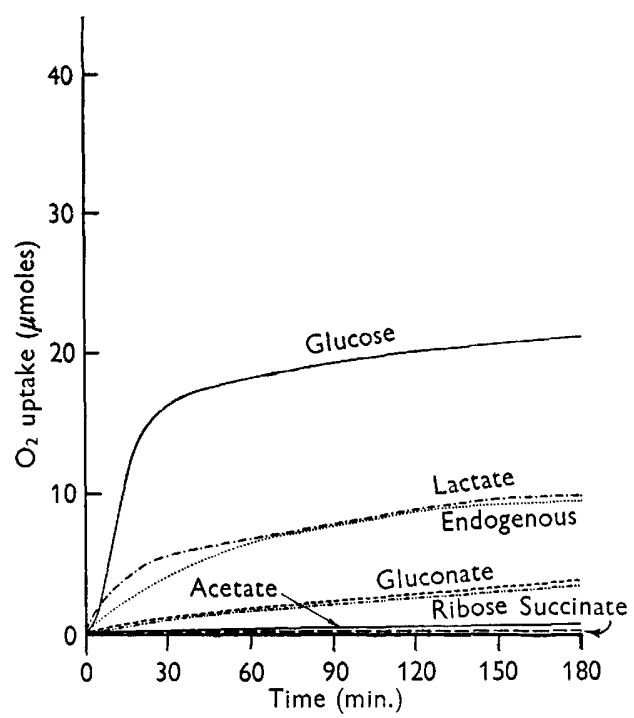

Fig. $1 b$

Fig. 1 a. Oxidation of various substrates by resting, broth-grown cocci of Staphylococcus aureus strain 3 A. Endogenous subtracted. Experimental details as in Table 1.

Fig. 1 b. Oxidation of various substrates by resting, glucose-grown cocci of Staphylococcus aureus strain $3 \mathrm{~A}$. Legend as in Fig. 1 a.

Table 2. Oxidation of citric acid cycle intermediates and of amino acids by Staphylococcus aureus $3 \mathrm{~A}$

Experimental details as in Table 1. An asterisk* indicates that the oxygen uptake showed an induction period. DL Forms of amino acids were used throughout except for the $\mathbf{L}$ isomer of ornithine. Leucine, valine, phenylalanine and tryptophan were not oxidized by either kind of cocci.

\section{Substrate}

Endogenous

Oxaloacetic acid

Citric acid

DL-Isocitric acid

$\alpha$-Ketoglutaric acid

Succinic acid

Fumaric acid

Malic acid

Serine

Alanine

Ornithine

Proline

Histidine

Glutamic acid

Aspartic acid

Glycine

\section{Oxygen uptake ( $\mu$ mole $\mathrm{O}_{2} / \mathrm{hr}$.) by washed staphylococci of strain 3 A grown

Without
glucose $\begin{gathered}\text { With } \\ \text { glucose }\end{gathered}$

$\begin{array}{cc}5 & 2 \\ 14 & 1 \\ 2^{*} & 0 \\ 3^{*} & 1 \\ 4 & 0 \\ 19 & 0 \\ 13^{*} & 1 \\ 13^{*} & 1 \\ 18 & 3^{*} \\ 19 & 0 \\ 10^{*} & 1 * \\ 6^{*} & 0 \\ 4^{*} & 0 \\ 34 & 16^{*} \\ 4^{*} & 1 \\ 19 & 6^{*}\end{array}$


extinction at $240 \mathrm{~m} \mu$ due to the double bond in fumaric acid. Aconitase (Racker, 1950) and isocitric dehydrogenase (Siebert, Dubuc, Warner \& Plaut, 1957) were not observed in our extracts. With G-cocci the case was entirely different: fumarase was not found in extracts of G-cocci and the activity of succinic dehydrogenase is markedly decreased (Fig. 2). These results seem to indicate that growth in glucose did inhibit the synthesis of some enzymes of the citric acid cycle (compare Table 5).

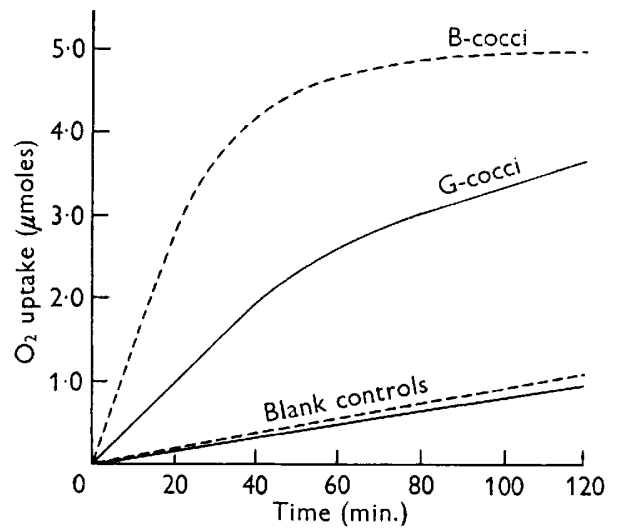

Fig. 2

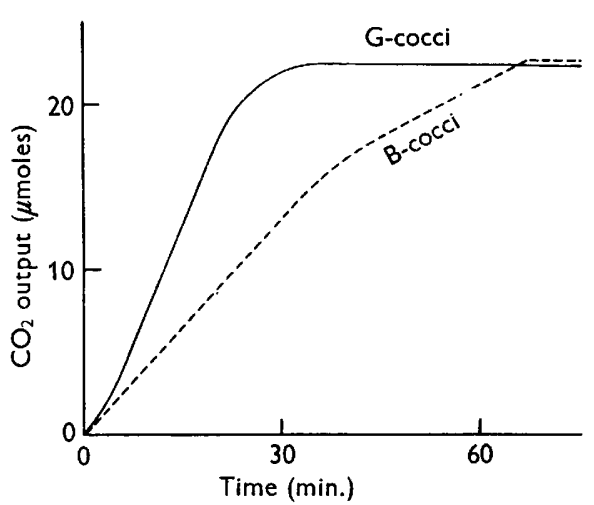

Fig. 3

Fig. 2. Determination of succinic dehydrogenase in broth-grown and glucose-grown cells of Staphylococcus aureus strain 3 A. A Warburg vessel contained: $100 \mu$ mole phosphate buffer pH 7.7, 0.5 ml. cell-free extract ( $5 \mathrm{mg}$. protein) and $2 \mathrm{mg}$. phenazinemethosulphate. As substrate $10 \mu$ mole of succinate were added. The centre well contained $0.1 \mathrm{ml} .20 \%$ KOH. Total volume $2.4 \mathrm{ml}$. Blanks not subtracted.

Fig. 3. Activity of glycolysis, under anaerobiosis, by resting, broth-grown and glucosegrown, cocci of Staphylococcus aureus strain $3 \mathrm{~A}$. The production of acid was followed by measuring the production of $\mathrm{CO}_{2}$ in $\mathrm{NaHCO}_{3}$ buffer. The Warburg vessels contained $15 \mathrm{mg}$. cells, expressed as dry wt., and $0.02 \mathrm{M}-\mathrm{NaHCO}_{3}$. From a side-arm $10 \mu$ mole glucose were added. Total volume $2 \cdot 4 \mathrm{ml}$, gas phase $\mathrm{N}_{2}+5 \% \mathrm{CO}_{2}$. Endogenous subtracted.

The oxidation of various amino acids by B-cocci and by G-cocci is shown in Table 2. In G-cocci the oxidation of amino acids was markedly decreased though glutamic acid was still oxidized appreciably. Furthermore, the oxidation of amino acids by G-cocei was always preceded by an induction period of about $20 \mathrm{~min}$. These results suggest that staphylococci grown in broth + glucose do not use amino acids for energy production. The oxidation of glutamic acid in the absence of a functional citric acid cycle seems remarkable since glutamic acid is easily concentrated in the cell (Gale, 1951) and seems to be the main substrate for endogenous oxygen uptake (Ramsey, 1962; Strasters, unpublished). A ready induction or expansion of the enzymes of the citric acid cycle may be supposed.

Glycolysis. Under anaerobic conditions glucose was broken down to $\mathrm{L}(+)$-lactic acid; in presence of arsenite this breakdown was quantitative (carbon recovery $\sim 1 \cdot 00$ ). Without arsenite small amounts of carbon dioxide were formed and the carbon recovery was too low (presumably due to assimilation and to oxidation of pyruvic acid by traces of oxygen or other hydrogen acceptors). The presence of a glycolytic system is, however, established beyond doubt.

The activity of the glycolytic system differed for B-cocci and G-cocci; the latter were more active (Fig. 3). The enzymes of the glycolytic system were demonstrated 
in cell-free extracts of both kinds of cocci (Tables 4 and 5). Phosphoglucoisomerase, phosphofructokinase and aldolase were of equal activity in both kinds of extracts, when determined separately. When the sequence of these enzymes together was estimated by studying the formation of triosephosphates from G-6-P the extract of G-cocci proved twice as active. Gald-3-P-dehydrogenase (Fig. 4) and lactic dehydrogenase were much more active in the extracts of G-cocci. Growth in glucose thus seems to increase some of the enzymes of the glycolytic system, thus explaining the enhanced glycolytic activity of G-cocci.

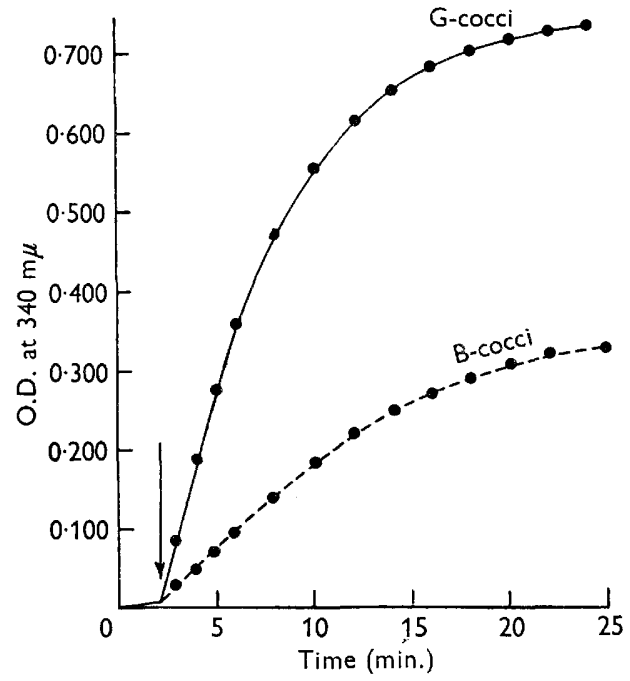

Fig. 4

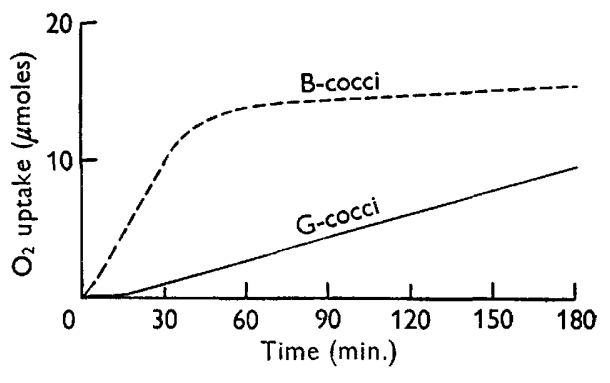

Fig. 5

Fig. 4. Determination of Gald-3-P-dehydrogenase in extracts of broth-grown and glucose-grown cocci by measuring the formed NADH in a Beckman DU spectrophotometer. A cuvette contained: $\mathbf{0 . 3} \mathrm{ml}$. cell-free extract ( $3 \mathrm{mg}$. protein), centrifuged at $70,000 \mathrm{~g}$ to diminish the NADH oxidase, $60 \mu$ mole Na-diethyl-barbiturate, $30 \mu$ mole NaF, $10 \mu$ mole cystein-HCl, $30 \mu$ mole arsenate and $0.33 \mu$ mole NAD. At $\downarrow 6 \mu$ mole F-1,6-P are added. Total volume $2 \cdot 7 \mathrm{ml}$.

Fig. 5. Oxygen uptake with $20 \mu$ mole Na pyruvate by resting cocci of Staphylococcus aureus strain $3 \mathrm{~A}$, grown with and without glucose. Endogenous subtracted. Experimental details as in Table 3.

Oxidative dissimilation of glucose. With glucose as a substrate oxygen uptake was greater for B-cocci than for G-cocci (Fig. 1 $a, b$ ). In both cases $\mathrm{CO}_{2}$ production equalled oxygen uptake (R.Q. about 1). Notwithstanding rigorous standardization the results of individual experiments were somewhat variable. For example, the oxygen uptake of G-cocci with $10 \mu$ mole glucose was $20 \cdot 8,17 \cdot 9,16 \cdot 1,17 \cdot 1,17 \cdot 3,19 \cdot 6,17 \cdot 7$, $17 \cdot 8 \mu$ mole $\mathrm{O}_{2}$ in eight experiments, with similar variations in $\mathrm{CO}_{2}$ production. The production of $20 \mu$ mole $\mathrm{CO}_{2}$ and uptake of $20 \mu$ mole $\mathrm{O}_{2}$ would be consistent with glycolytic fission and subsequent oxidation of pyruvic acid to acetic acid and $\mathrm{CO}_{2}$. The results of the determination of the reaction products are given in Table 3. No lactic acid, amino acids or other carboxy acids were found. Neither ethanol nor ketosugars were observed in the filtrate. The main products were $\mathrm{CO}_{2}$ and acetic acid, but the amount of $\mathrm{CO}_{2}$ was much more and the amount of acetic acid much less than would be consistent with the above hypothesis (see equation on 
p. 227). A further oxidation of acetic acid by the citric acid cycle might be supposed as an explanation. However, even in presence of arsenite an appreciable amount of $\mathrm{CO}_{2}$ was formed which cannot very well have been derived from pyruvic acid (compare Table 3).

Table 3. Quantitative determination of products formed by the dissimilation of several substrates by resting Staphylococcus aureus cells of strain $\mathbf{3} \mathbf{A}$

The experiments were done as described in Table 1 , but with equiv. $4 \mathrm{mg}$. dry wt. organism/vessel. In aerobic dissimilation the $\mathrm{CO}_{2}$ was measured by the direct method. In anaerobic dissimilation the gas phase was $\mathrm{N}_{2}$ and there was no $\mathrm{KOH}$ in the centre well. Where noted $5 \mu$ mole $\mathrm{Na}$-arsenite $/ \mathrm{ml}$. were present. The amount of substrate was 10 $\mu$ mole, but with pyruvate $20 \mu$ mole. After an incubation for 150 min. the cocci were centrifuged down and the products determined in the supernatant fluid. The values recorded are the mean of two determinations; endogenous values subtracted.

\begin{tabular}{|c|c|c|c|c|c|c|c|c|c|c|}
\hline \multirow{2}{*}{$\begin{array}{c}\text { Cocei } \\
\text { grown } \\
\text { in broth } \\
\text { with } \\
\text { addenda }\end{array}$} & \multirow[b]{2}{*}{$\begin{array}{l}\text { Gas } \\
\text { phase }\end{array}$} & \multirow[b]{2}{*}{$\begin{array}{l}\text { Sub- } \\
\text { strate }\end{array}$} & \multirow[b]{2}{*}{$\begin{array}{c}\text { Presence } \\
\text { of } \\
\text { arsenite }\end{array}$} & \multicolumn{7}{|c|}{ Compounds determined as $\mu$ mole/vessel } \\
\hline & & & & $\begin{array}{c}\text { Unused } \\
\text { substrate }\end{array}$ & $\begin{array}{l}\text { Acetic } \\
\text { acid }\end{array}$ & $\begin{array}{l}\text { Pyruvic } \\
\text { acid }\end{array}$ & $\begin{array}{c}\text { Lactic } \\
\text { acid }\end{array}$ & AMC* & $\mathrm{O}_{2}$ & $\mathrm{CO}_{2}$ \\
\hline Nil & Air & Glucose & - & $0 \cdot 1$ & $6 \cdot 2$ & $0 \cdot 0$ & $\mathbf{0} \cdot \mathbf{0}$ & 00 & $27 \cdot 8$ & $27 \cdot 7$ \\
\hline Nil & Air & Glucose & + & $\mathbf{3 \cdot 3}$ & $0 \cdot 2$ & $7 \cdot 9$ & $0 \cdot 0$ & $0 \cdot 9$ & $8 \cdot 7$ & $6 \cdot 6$ \\
\hline Glucose & Air & Glucose & - & $0 \cdot 0$ & $8 \cdot 0$ & $0 \cdot 2$ & 0.0 & 0.0 & $20 \cdot 5$ & $21 \cdot 3$ \\
\hline Glucose & Air & Glucose & + & $0 \cdot 1$ & $0 \cdot 6$ & $12 \cdot 0$ & 0.0 & 1.9 & $12 \cdot 8$ & $10 \cdot 4$ \\
\hline Nil & $\mathbf{N}_{2}$ & Pyruvate & - & $0 \cdot 5$ & $9 \cdot 4$ & - & $6 \cdot 9$ & $\mathbf{0} \cdot \mathbf{0}$ & - & $8 \cdot 7$ \\
\hline Nil & $\mathbf{N}_{2}$ & Pyruvate & + & $15 \cdot 6$ & $1 \cdot 8$ & - & $1 \cdot 7$ & $0 \cdot 6$ & - & $2 \cdot 1$ \\
\hline Glucose & $\mathbf{N}_{2}$ & Pyruvate & - & 0.7 & $9 \cdot 4$ & - & $7 \cdot 7$ & $0 \cdot 0$ & - & $8 \cdot 2$ \\
\hline Glucose & $\mathbf{N}_{2}$ & Pyruvate & + & $18 \cdot 5$ & $1 \cdot 0$ & - & $1 \cdot 1$ & 0.3 & - & $2 \cdot 3$ \\
\hline Nil & Air & Pyruvate & - & $0 \cdot 0$ & $11 \cdot 1$ & - & $0 \cdot 0$ & 0.0 & $15 \cdot 2$ & $24 \cdot 8$ \\
\hline Nil & Air & Pyruvate & + & $15 \cdot 5$ & 2.9 & - & $0 \cdot 1$ & 0.5 & $0 \cdot 3$ & $2 \cdot 7$ \\
\hline Glucose & Air & Pyruvate & - & $2 \cdot 0$ & $15 \cdot 2$ & - & 0.0 & 0.0 & $8 \cdot 8$ & $16 \cdot 7$ \\
\hline Glucose & Air & Pyruvate & + & $18 \cdot 8$ & $1 \cdot 5$ & - & $0 \cdot 3$ & $0 \cdot 1$ & $0 \cdot 6$ & $0 \cdot 2$ \\
\hline Ribose & Air & Ribose & - & 0.6 & $5 \cdot 8$ & $0 \cdot 1$ & $0 \cdot 0$ & 0.0 & 18.9 & $19 \cdot 5$ \\
\hline Ribose & Air & Ribose & + & $6 \cdot 5$ & $2 \cdot 1$ & $3 \cdot 2$ & 0.0 & $0 \cdot 3$ & $2 \cdot 2$ & $0 \cdot 8$ \\
\hline
\end{tabular}

It will be observed that the carbon recovery was too low. It will be shown below that this was partly due to assimilation, partly to diminution of endogenous metabolism by addition of substrate and, for a minor part, to the formation of other products. Thus the results described in this section suggest that a second system for the oxidation of glucose must exist. This system, presumably the pentose cycle, would then be much more active in B-cocci.

Dissimilation of pyruvic acid. Under anaerobic conditions pyruvic acid was mainly broken down by dismutation to lactic acid, acetic acid and $\mathrm{CO}_{2}$ (Table 3). As far as final products are concerned, G-cocci and B-cocci behaved similarly. The rate of $\mathrm{CO}_{2}$ production by G-cocci was, however, much slower (about 1/4) than that by B-cocci. In presence of arsenite the dismutation was slowed and a second mechanism which produced acetylmethylcarbinol and $\mathrm{CO}_{2}$ took over. The activity of this mechanism was very dependent on the concentration of $\mathrm{Mg}^{2+}$ and thiamine. Under aerobic conditions (Table 3 ) pyruvic acid was oxidized to acetic acid and $\mathrm{CO}_{2}$. The amount of $\mathrm{CO}_{2}$ was in excess, especially for B-cocci, suggesting that some of the acetic acid was oxidized by the citric acid cycle, which was more active in B-cocci. The oxidation of acetic acid by the citric acid cycle when pyruvic acid is offered as a 
substrate does not necessarily mean that this also will happen with glucose as a substrate since the (intermediate) concentration of pyruvic will be less in the latter case; indeed inhibition by arsenite was less complete with pyruvic acid as substrate (Table 3). The rate of pyruvate oxidation is much higher for B-cocci than for G-cocci (Fig. 5). Growth in glucose thus seemed to suppress pyruvic oxidation in accordance with the results of Sevag \& Swart (1947).

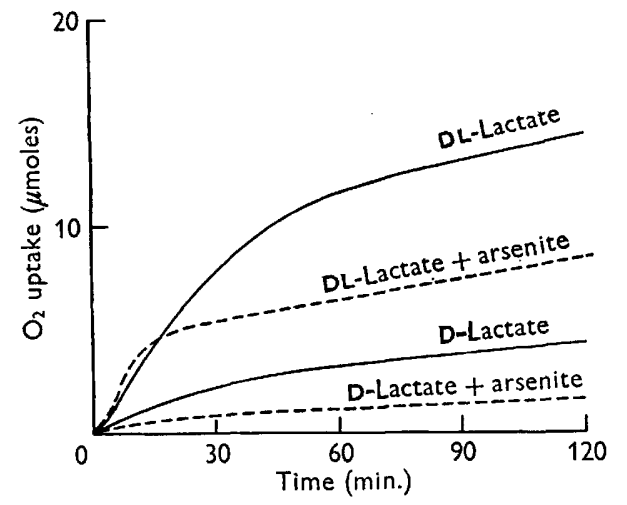

Fig. 6

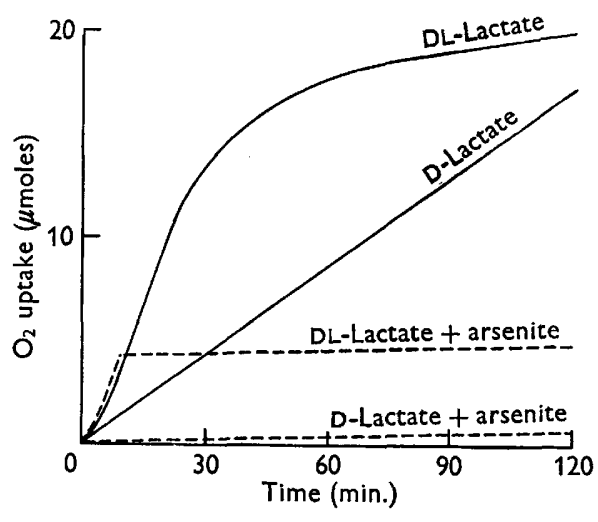

Fig. 7

Fig. 6. Oxygen uptake with $20 \mu$ moles Li-DL-lactate and Li-D-lactate, with and without $5 \mu$ moles arsenite/ml., by resting, glucose-grown cocci of Staphylococcus aureus strain 3 A. The experiment is done as described in Table 1. Endogenous subtracted.

Fig. 7. Same experiments as in Fig. 6 with broth-grown cocci.

The dissimilation of lactic acid. DL-Lactate is oxidized rapidly by B-cocci and G-cocci in contradistinction to $\mathrm{D}$-lactate, which is oxidized at a much slower rate (Figs. 6, 7). The results are in accordance with the presence of a $\mathrm{L}(+)$-lactic dehydrogenase. As can be seen from Table 5 this enzyme is more active in G-cocci. The lower rate of oxidation in Fig. 6 was due to the suppression of the subsequent pyruvic oxidation in G-cocci. No racemase was present; the oxygen uptake, with or without arsenite, with D-lactate was completely different from the oxygen uptake with DL-lactate and only L-lactic acid was formed from glucose under anaerobiosis. Peculiarly, the oxidation of D-lactate was completely inhibited by arsenite. The mechanism of the D-lactate oxidation remains obscure.

The dissimilation of ribose and gluconate. Neither B-cocci, G-cocci nor ribosegrown cocci metabolized ribose anaerobically. This suggests that no phosphoketolase was present, as in heterofermentative lactobacilli (see also Table 5). G-cocci did not oxidize ribose (Fig. $1 b$ ); supplied ribose was recovered quantitatively. Ribose-grown cocci oxidized ribose with an R.Q. of about 1 and with acetic acid and $\mathrm{CO}_{2}$ as main products (Table 3). Arsenite decreased the rate of ribose oxidation with accumulation of pyruvic acid and the formation of acetylmethylcarbinol. Since phosphoketolase was absent these results are best explained by supposing that ribose after phosphorylation was transformed by transaldolase-transketolase to hexosephosphate, which was then broken down (by the pentose cycle or by the glycolytic system) to pyruvic acid. The large excess of $\mathrm{CO}_{2}$ with regard to acetic acid, in the experiment without arsenite, suggests oxidation of pyruvic acid by the citric acid cycle or a contribution of the dehydrogenases of the pentose cycle. The 
accumulation of acetic acid in the experiment with arsenite is puzzling, considering the almost complete inhibition of acetic acid formation by arsenite in the experiments with glucose. With gluconate the oxygen consumption and $\mathrm{CO}_{2}$ production by B-cocci were, respectively, $0.5 \mu$ mole and $1 \mu$ mole $/ \mu$ mole substrate higher than in experiments with ribose, as would be expected on the assumption that gluconate was phosphorylated and oxidized by 6-P-G-dehydrogenase to pentose phosphate. These results seem to indicate that transaldolase, transketolase and 6-P-G-dehydrogenase are present in Staphylococcus aureus, thus suggesting the presence of a complete pentose cycle.

\section{Demonstration of the enzymes of the pentose cycle in cell-free extracts}

Kinases. Kinases were demonstrated by the method of Colowick \& Kalckar (1943). The results for B-cocci are given in Fig. 8 and for several other kinds of cocci in Table 4. Glucokinase and phosphofructokinase were always present. The systematic absence of fructokinase is remarkable considering the rapid oxidation of fructose. The absence of ribokinase and gluconokinase from G-cocci is conspicuous. The absence of these enzymes would alone be sufficient explanation for the suppression of the oxidation of ribose and gluconic acid by G-cocci. Growth on ribose induced the formation of ribokinase and gluconokinase.

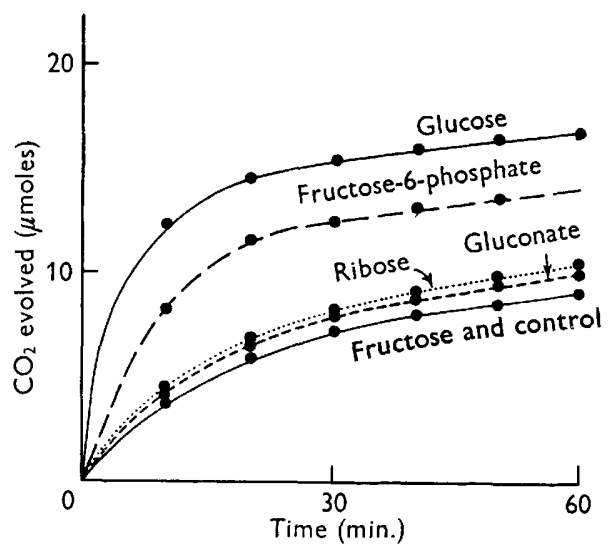

Fig. 8

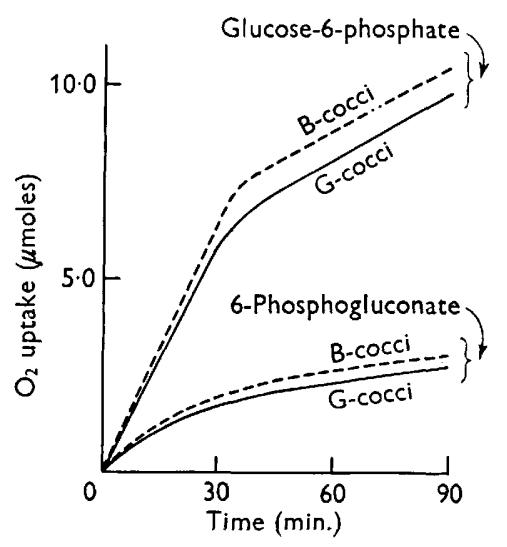

Fig. 9

Fig. 8. Determination of kinases in a cell-free extract of broth-grown cocci. Measured as $\mathrm{CO}_{2}$ evolution from $0.02 \mathrm{M}-\mathrm{NaHCO}_{3}$ buffer. A Warburg vessel contained: $0.5 \mathrm{ml}$. cellfree extract ( $5 \mathrm{mg}$. protein), $20 \mu$ mole ATP, $20 \mu$ mole $\mathrm{MgCl}_{2}, 25 \mu$ mole $\mathrm{NaF}$ and $10 \mu$ mole of the indicated substrates. Total volume $2 \cdot 4 \mathrm{ml}$. Gas phase $\mathrm{N}_{2}+5 \% \mathrm{CO}_{2}$.

Fig. 9. Determination of G-6-P and 6-P-G-dehydrogenases in cell-free extracts of broth-grown and glucose-grown cocci of Staphylococcus aureus strain $3 \mathrm{~A}$ by following the oxygen uptake. A Warburg vessel contained: $90 \mu$ mole Tris-buffer pH 7.8, $50 \mu$ mole $\mathrm{MgCl}_{2}, 0.5 \mu$ mole TPP, $5 \mu$ mole NADP, $2 \mathrm{mg}$. PMS and $0.5 \mathrm{ml}$. extract (5 mg. protein). The centre well contained $0.1 \mathrm{ml} .20 \%$ KOH. As substrate $10 \mu$ mole G-6-P or 6-P-G were added from a side-arm. Total volume $2.4 \mathrm{ml}$. Blanks subtracted.

Dehydrogenases. G-6-P and 6-P-G dehydrogenases were demonstrated by following NADP reduction spectrophotometrically and by $\mathrm{O}_{2}$ consumption in Warburg vessels in the presence of phenazine methosulphate. Both dehydrogenases were equally active in B-cocci and in G-cocci (Fig. 9). 


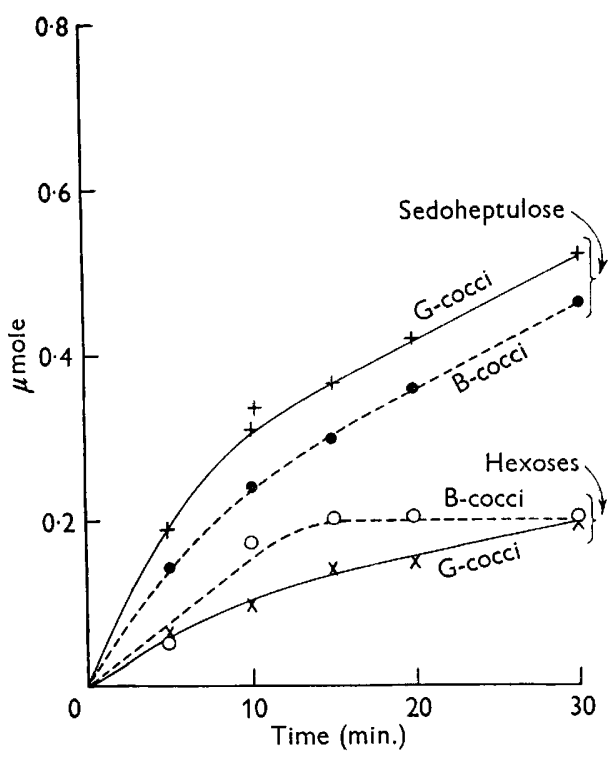

Fig. 10

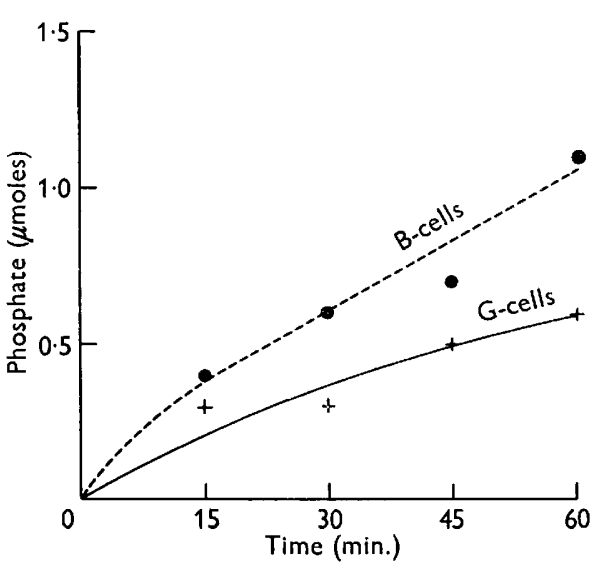

Fig. 11

Fig. 10. Formation of hexoses and sedoheptulose by cell-free extracts of broth-grown and glucose-grown cocci of Staphylococcus aureus strain $3 \mathbf{A}$ during incubation with R-5-P

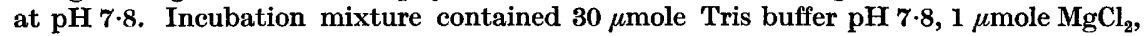
$0.03 \mu$ mole TPP, $9 \mu$ mole R-5-P and $0.05 \mathrm{ml}$. extract $(0.5 \mathrm{mg}$. protein). Total volume $1.0 \mathrm{ml}$. The reaction was stopped with $1.0 \mathrm{ml}$. $10 \%$ TCA and centrifuged. Hexoses and sedoheptuloses were determined in the supernatant.

Fig. 11. Determination of hexosediphosphatase in cell-free extracts of broth-grown and glucose-grown cocci of Staphylococcus aureus strain $3 \mathrm{~A}$. The formation of inorganic phosphate from $\mathrm{F}-1,6-\mathrm{P}$ is followed. The incubation mixture contained: $25 \mu \mathrm{mole}$ borate buffer pH 9.5 and $0.4 \mathrm{ml}$. extract (4 mg. protein). As substrate $5 \mu$ mole F-1,6-P were added. Total volume $1.2 \mathrm{ml}$. The reaction was stopped by heating the mixture $5 \mathrm{~min}$. at $100^{\circ}$. The inorganic phosphate was determined as described by Fiske \& SubbaRow (1925). Controls subtracted.

Table 4. Kinases which were determined in cell-free extracts of Staphylococcus aureus strain $3 \mathrm{~A}$ grown in broth with $\mathbf{0} \cdot \mathbf{1} \%$ of various carbohydrates. The kinases were determined as described in legend to Fig. 8

Staphylococci grown with

$\begin{array}{ccc}\text { No Glucose Gluconate Ribose } & \text { Fructose } \\ \text { addition } & \text { Relative amounts of enzyme } & \end{array}$

\begin{tabular}{|c|c|c|c|c|c|}
\hline & & & & & \\
\hline Glucokinase & ++ & ++ & $+t$ & ++ & ++ \\
\hline Gluconokinase & \pm & - & + & + & - \\
\hline Ribokinase & \pm & - & \pm & + & - \\
\hline Fructokinase & - & - & - & - & - \\
\hline Phosphofructokinase & + & + & + & + & + \\
\hline
\end{tabular}

$$
++=\text { very active }+=\text { active } \pm=\text { weakly active }-=\text { absent. }
$$


Transaldolase, transketolase and the pentose isomerases. These enzymes were demonstrated by incubation of extracts with R-5-P, followed by spectrophotometric estimation of sedoheptulose and hexose phosphates according to Newburgh \& Cheldelin (1955) and Kulka (1956). The results are presented in Fig. 10 for cell extracts at $\mathrm{pH} 7 \cdot 8$. At this $\mathrm{pH}$ value reduced glutathione (GSH) was without influence. With the same extracts at $\mathrm{pH} 6.0$ in presence of GSH an even more rapid formation of sedoheptulose and hexoses was observed, but no activity was found without GSH. Again, a definite difference between B-cocci and G-cocci was not observed. The impression was obtained that a GSH-independent system with optimal activity at $\mathrm{pH} 7 \cdot 8$ and a GSH-dependent system with optimal activity at $\mathrm{pH} 6 \cdot 0$ are present in Staphylococcus aureus. There was no appreciable difference however between G-cocci and B-cocci.

Hexosediphosphatase was determined by liberation of inorganic phosphate from fructose-1,6-diphosphate; the results are shown in Fig. 11. B-cocci are the more active.

Table 5. Presence of enzymes in cell-free extracts from cells of Staphylococcus aureus strain $3 \mathrm{~A}$ grown with and without glucose

\begin{tabular}{|c|c|c|c|}
\hline \multirow[b]{2}{*}{ Enzyme } & \multicolumn{2}{|c|}{ Activity in } & \multirow[b]{2}{*}{ Determined as described by } \\
\hline & B-cells & G-cells & \\
\hline Phosphoglucoisomerase & + & + & Jensen, Altschuller \& Bard (1957) \\
\hline Phosphofructokinase & + & + & Colowick \& Kalckar (1943) \\
\hline Aldolase & + & + & Sibley \& Lehninger (1949) \\
\hline Gald-3-P-dehydrogenase & + & ++ & Shankar \& Bard (1956) \\
\hline Lactic-dehydrogenase & + & ++ & Neilands (1955) \\
\hline G-6-P-Dehydrogenase & + & + & Modification of van den Hamer (1960) \\
\hline 6-P-Gluconolactonase & + & + & . \\
\hline 6-P-G-Dehydrogenase & + & + & Modification of van den Hamer (1960) \\
\hline TK-TA-Pathway & + & + & . \\
\hline Hexosediphosphatase & ++ & + & - \\
\hline Succinic dehydrogenase & $+t$ & + & . \\
\hline Fumarase & + & - & - \\
\hline Malic dehydrogenase & + & + & - \\
\hline Glucokinase & + & +1 & \\
\hline Gluconokinase & \pm & - & \\
\hline Ribokinase & \pm & - & Colowick \& Kalckar (1943) \\
\hline Fructokinase & - & $-J$ & \\
\hline Entner-Doudoroff pathway & $(-)^{*}$ & . & Vandemark \& Wood (1956) \\
\hline Phosphoketolase & $(-)^{*}$ & . & Heath et al. (1958) \\
\hline Cytochromes & ++ & + & Chance (1952) \\
\hline
\end{tabular}

Phosphoketolase. By using the method of Heath, Hurwitz, Horecker \& Ginsburg (1958) with ribose-5-phosphate as a substrate no acetylphosphate formation was observed in extracts of gluconate-grown staphylococci. The method was checked with good results with extracts of Lactobacillus casei, which we have found to possess very active phosphoketolase when grown with gluconate.

Phosphofructoketolase. Tested by the method of Schramm, Klybas \& Racker (1958) a very small activity of this enzyme was found in extracts of gluconategrown cocci. The method was checked with good results with extracts of Acetobacter xylinum. The presence of phosphofructoketolase in Staphylococcus aureus $\mathbf{3}$ A cannot 
be excluded. The results of all enzyme studies are summarized in Table 5 . The results indicate that all the enzymes of the pentose cycle are present in the Staphylococcus aureus strains used. They were in general equally active in B-cocci and in G-cocci with the exception of hexosediphosphatase.

Cytochromes. The decreased activity of the citric acid cycle in glucose-grown cocci raised the question whether the electron transfer system was also involved. The differential spectrum of oxidized and reduced coccal suspensions in $67 \%$ glucose was measured spectrophotometrically according to Chance (1952); the quantity of cytochromes was estimated from the differences between maxima and minima in the differential spectrum (Fig. 12). From these data a decrease of the cytochromes of about $40 \%$ in G-cocci compared with B-cocci was calculated. Growth in glucose indeed seems to decrease the activity of the cytochrome system.

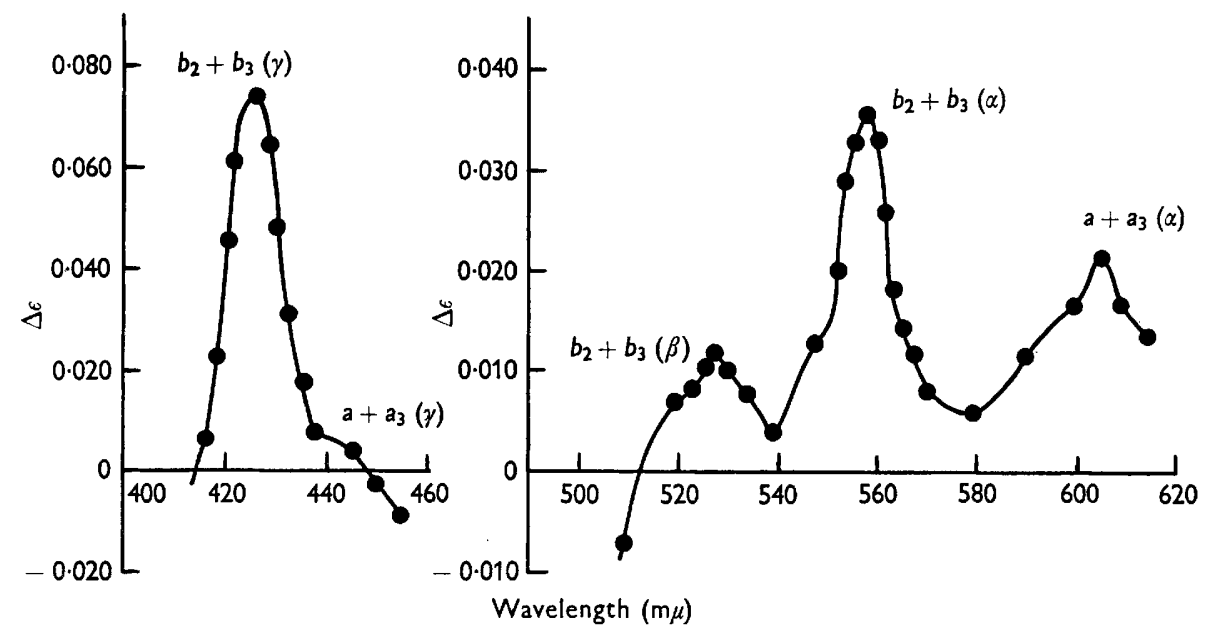

Fig. 12. Differential spectrum of cocci grown without glucose, suspended in $67 \%$ glucose (15 mg./ml. cocci as dry weight).

\section{Contribution of various oxidative systems in carbohydrate dissimilation}

Evidence has been submitted for the presence of two mechanisms for glucose breakdown: the pentose cycle; glycolysis with subsequent oxidation of pyruvic acid, with or without involvement of the citric acid cycle. The participation of these systems in carbohydrate breakdown was studied by incubating suspensions of cocci with $\left[1{ }^{14} \mathrm{C}\right]$ glucose, $\left[\mathrm{U}^{-14} \mathrm{C}\right]$ glucose or $\left[{ }^{1-14} \mathrm{C}\right]$ ribose and determining the ${ }^{14} \mathrm{C}$ activity in the cells, in the surrounding fluid and in the $\mathrm{CO}_{2}$. The results are summarized in Table 6. B- and G-cocci produce labelled $\mathrm{CO}_{2}$ from $\left[1-{ }^{14} \mathrm{C}\right]$ glucose. This is proof that the pentose cycle is engaged in glucose breakdown in both kinds of cocci, though more actively in B-cocci. With $\mathrm{B}$-cocci, with or without arsenite, $64 \%$ of the activity from $\left[1-{ }^{14} \mathrm{C}\right]$ glucose was recovered as $\mathrm{CO}_{2}$. This means that at least $64 \%$ of the glucose went through the cycle. The flow through the cycle as percentage of actual hexosephosphate pool is probably greater (Wood \& Katz, 1958; Dawes \& Holms, $1958 c$ ) depending on the degree of recycling.

An estimation of the degree of recycling can be obtained by comparing the results with $\left[1{ }^{14} \mathrm{C}\right]$ glucose and $\left[\mathrm{U}^{14} \mathrm{C}\right]$ glucose. From the first $\mathrm{C}$-atom $64 \%$ was split off as 
$\mathrm{CO}_{2}$ as appears from the data with $\left[{ }^{1-14} \mathrm{C}\right]$ glucose. This means that with $\left[\mathrm{U}-{ }^{14} \mathrm{C}\right]-$ glucose $64 / 6=11 \%$ of the total activity was derived from the first C-atom. From $10 \mu$ mole glucose $6 \cdot 2 \mu$ mole acetic acid were formed via pyruvic acid, corresponding to $\mathbf{6} \cdot 2 \mu$ mole $\mathrm{CO}_{2}$ or about $10 \%$ of the total activity. From [U-14C]glucose $11+10=21 \%$ of the total activity would be expected in the carbon dioxide if no recycling occurred. Actually $53 \%$ was found, leaving $32 \%$ of the activity which must have been split off as $\mathrm{CO}_{2}$ by recycling (at least 3 cycles).

\section{Table 6. Radioactivity in $\mathrm{CO}_{2}$ and cells after oxidation of radioactive glucose and ribose}

Experimental details are described in Methods

The activity of the added $\left[1{ }^{14} \mathrm{C}\right]$ glucose and $\left[1-{ }^{14} \mathrm{C}\right]$ ribose was $0 \cdot 05 \mu \mathrm{C}$, of [U-14 $\left.\mathrm{C}\right]-$ glucose $\mathbf{0} \cdot \mathbf{1} \mu \mathrm{C}$.

\begin{tabular}{|c|c|c|c|c|c|c|c|}
\hline \multirow{2}{*}{$\begin{array}{l}\text { Kind of } \\
\text { cells }\end{array}$} & \multirow[b]{2}{*}{ Arsenite } & \multirow{2}{*}{\multicolumn{2}{|c|}{$\begin{array}{c}\text { Activity of } \\
\text { consumed } \\
\text { substr. } \\
\text { (counts/min.) }\end{array}$}} & \multirow{2}{*}{$\begin{array}{c}\text { Recovery } \\
\text { in } \%\end{array}$} & \multicolumn{3}{|c|}{$\%$ of recovery in } \\
\hline & & & & & $\mathrm{CO}_{2}$ & Filtrate & Cells \\
\hline $\mathbf{B}$ & -1 & & $\int 27,851$ & 96 & 64 & 27 & 9 \\
\hline B & $+\}$ & {$\left[1-{ }^{14} \mathrm{C}\right]$ glucose } & $\{16,710$ & 92 & 64 & 33 & 3 \\
\hline $\mathbf{B}$ & -1 & & $\{50,532$ & 95 & 53 & 32 & 15 \\
\hline B & $+\}$ & {$\left[\mathrm{U}-{ }^{14} \mathrm{C}\right]$ glucose } & $\{39,415$ & 85 & 19 & 72 & 9 \\
\hline $\mathbf{G}$ & -1 & & $\{27,851$ & 98 & 47 & 43 & 10 \\
\hline G & $+\}$ & {$\left[1-{ }^{14} \mathrm{C}\right]$ glucose } & $\{27,573$ & 88 & 38 & 59 & 3 \\
\hline $\mathbf{G}$ & -1 & [I_14C]cluese & $\int 50,532$ & 98 & 39 & 48 & 13 \\
\hline $\mathbf{G}$ & $+\}$ & {$\left[\mathrm{U}-{ }^{-14} \mathrm{C}\right] \mathrm{g} h \mathrm{cose}$} & $\{50,532$ & 95 & 18 & 75 & 7 \\
\hline Ribose-grown & -1 & & $(34,044$ & 99 & 58 & 25 & 17 \\
\hline Ribose-grown & $+\}$ & {$[1-14 \mathrm{C}] \mathrm{ribose}$} & $\{17,200$ & 96 & 32 & 57 & 11 \\
\hline
\end{tabular}

In presence of arsenite $16 \%$ activity would be expected as $\mathrm{CO}_{2}$ without recycling; $19 \%$ was found. This seems to indicate that recycling was decreased in presence of arsenite.

With G-cocci the activity of the pentose cycle was much less; $47 \%$ of the activity of $\left[{ }^{1-14} \mathrm{C}\right]$ glucose appeared as $\mathrm{CO}_{2}$, with arsenite only $38 \%$. Considering the decreased activity of the pentose cycle in G-cocci this difference might be due to some shuffling via transaldolase-transketolase (Stjernholm \& Wood, 1960) resulting in some labelling of the carboxyl group of pyruvic acid from which labelled $\mathrm{CO}_{2}$ could then be derived. In presence of arsenite the labelled pyruvic would remain in solution and less labelled $\mathrm{CO}_{2}$ would appear. If this explanation be accepted it would mean that the amount of $\left[1{ }^{14} \mathrm{C}\right]$ glucose passing through the cycle would be nearer $38 \%$ than $47 \%$.

Assuming no recycling, $20 \%$ of the activity of $\left[\mathrm{U}-{ }^{14} \mathrm{C}\right]$ glucose would be expected in the $\mathrm{CO}_{2}$, whereas $39 \%$ was found. Also in G-cocci recycling seemed to occur; this also was suppressed in presence of arsenite.

The results with $\left[1-{ }^{14} \mathrm{C}\right]$ ribose (Table 6 ) show that $58 \%$ of the activity appeared as $\mathrm{CO}_{2}$. Assuming conversion of ribose to hexosephosphate with subsequent glycolysis, two-fifths of the resulting pyruvic acid would be labelled in the carboxyl group and $\mathbf{3 \cdot 3} \mu$ mole labelled $\mathrm{CO}_{2}$ would be expected, or $33 \%$ of the activity. Since $58 \%$ was found it is obvious that at least $25 \%$ of the $\left[1-{ }^{14} \mathrm{C}\right]$ ribose was oxidized via the dehydrogenases of the pentose cycle. These results prove beyond doubt that the pentose cycle actively participates in carbohydrate breakdown by Staphylococcus aureus. 


\title{
Carbon recoveries, assimilation
}

The low carbon recoveries in some of the previous experiments might have several explanations. The experiments with labelled substrates permitted some of these to be tested and some of the balance-equations could be corrected.

Assimilation. After incubation of cocci with $\left[\mathrm{U}-{ }^{14} \mathrm{C}\right]$ glucose the radioactivity of the cocci was $15 \%$ and $13 \%$ for B-cocci and G-cocci, respectively (Table 6 ). These values are a direct measure of the amount of substrate assimilated and show that assimilation was indeed one of the explanations of the low apparent carbon recovery. The radioactivity of the cocci after incubation with $\left[1-{ }^{14} \mathrm{C}\right]$ ribose was a less reliable measure for the assimilation of ribose, since some randomization may occur by the transaldolase and transketolase in the pentose cycle. There is, however, no doubt that some assimilation took place.

\section{Table 7. Reduction of endogenous $\mathrm{CO}_{2}$ production by substrate}

\begin{abstract}
The amount of $\mathrm{CO}_{2}$ produced from $\left[\mathrm{U}^{14} \mathrm{C}\right]$ glucose as calculated from the radioactivity in the $\mathrm{CO}_{2}$ is compared with the amount of $\mathrm{CO}_{2}$ as measured directly in Warburg vessels. Subtracting the first from the second gives the value for the true endogenous $\mathrm{CO}_{2}$ production. Incubation time $150 \mathrm{~min} ., 10 \mu$ mole of substrate. The substrate was used completely except for B-cells with arsenite, in which case 6.7 $\mu$ mole were consumed. Cell density, $4 \mathrm{mg} . / \mathrm{ml}$.
\end{abstract}

\begin{tabular}{|c|c|c|c|c|c|c|}
\hline \multirow[b]{2}{*}{$\begin{array}{l}\text { Kind of } \\
\text { cells }\end{array}$} & \multirow[b]{2}{*}{ Arsenite } & \multirow[b]{2}{*}{$\begin{array}{l}\text { Carbon } \\
\text { recovery }\end{array}$} & \multicolumn{4}{|c|}{$\mu$ mole $\mathrm{CO}_{2}$} \\
\hline & & & $\begin{array}{c}\text { Calculated } \\
\text { from } \\
\text { activity }\end{array}$ & $\begin{array}{c}\text { In } \\
\text { Warburg } \\
\text { with } \\
\text { substr. }\end{array}$ & \begin{tabular}{l}
\multicolumn{1}{c}{ In } \\
Warburg \\
without \\
substr.
\end{tabular} & $\begin{array}{l}\text { 'True en- } \\
\text { dogenous' }\end{array}$ \\
\hline B & - & 0.67 & $31 \cdot 8$ & $32 \cdot 4$ & $4 \cdot 8$ & $0 \cdot 6$ \\
\hline B & + & 0.85 & $7 \cdot 4$ & $10 \cdot 4$ & $3 \cdot 8$ & $3 \cdot 0$ \\
\hline $\mathbf{G}$ & - & 0.63 & $23 \cdot 4$ & $25 \cdot 6$ & $4 \cdot 4$ & $2 \cdot 2$ \\
\hline $\mathbf{G}$ & + & 0.93 & $10 \cdot 8$ & $13 \cdot 6$ & $3 \cdot 2$ & $2 \cdot 8$ \\
\hline
\end{tabular}

Suppression of endogenous metabolism. The supply of a substrate can decrease the endogenous $\mathrm{O}_{2}$ uptake (Dawes \& Holms, 1958b; Gronlund \& Campbell, 1961). Under such circumstances the usual procedure of subtracting endogenous oxygen consumption or product formation from the experimental values (which was followed in our experiments) would be wrong, the final data being too low.

By comparing the activity of the $\mathrm{CO}_{2}$ formed from $\left[\mathrm{U}_{-}{ }^{14} \mathrm{C}\right]$ glucose with the total amount of $\mathrm{CO}_{2}$ evolved the actual amount of $\mathrm{CO}_{2}$ derived from endogenous sources can be calculated. This amount of $\mathrm{CO}_{2}$ was always lower than the apparent value obtained in the Warburg vessel without substrate (Table 7). The difference depends on experimental conditions and was smaller in those cases where carbon recoveries were better. With the help of these data the carbon recoveries could be corrected.

Additional products. The radioactivity of the filtrate in the experiments with labelled glucose should tally with the amount of metabolic products (mainly acetic acid). With B-cocci it was found that after distillation of the filtrate to remove acetic acid the residue still contained labelled material equivalent to $9 \%$ of the total activity. After purification and chromatography three different substances with about equal radioactivity were shown; one of these was probably succinic acid. 
Balance-equations. With the additional information about assimilation and suppression of endogenous metabolism, but excluding additional products, the balanceequations for glucose were corrected with the following results:

Broth-grown organisms :

$10 \cdot 0$ glucose $+30 \cdot 0 \mathrm{O}_{2} \rightarrow 31 \cdot 8 \mathrm{CO}_{2}+6.9$ acetic acid $+9 \cdot 0 \mathrm{C}$ assimilated; carbon recovery 0.91 (excluding additional products).

Broth-grown organisms with arsenite:

$10 \cdot 0$ glucose $+13 \cdot 6 \mathrm{O}_{2} \rightarrow 11 \cdot 0 \mathrm{CO}_{2}+0 \cdot 4$ acetic acid $+11 \cdot 7$ pyruvic acid $+5 \cdot 4 \mathrm{C}$ assimilated; carbon recovery 0.96 .

Glucose-grown organisms :

$10 \cdot 0$ glucose $+22 \cdot 2 \mathrm{O}_{2} \rightarrow 23 \cdot 4 \mathrm{CO}_{2}+9 \cdot 0$ acetic acid $+0 \cdot 2$ pyruvic acid $+7 \cdot 8 \mathrm{C}$ assimilated; carbon recovery $0 \cdot 83$.

Glucose-grown organisms + arsenite:

$10 \cdot 0$ glucose $+13 \cdot 0 \mathrm{O}_{2} \rightarrow \mathbf{1 0} \cdot 8 \mathrm{CO}_{2}+0.7$ acetic acid $+12 \cdot 0$ pyruvic acid $+1 \cdot 9$ acetylmethylcarbinol $+4 \cdot 2 \mathrm{C}$ assimilated; carbon recovery $1 \cdot 00$.

For ribose the suppression of endogenous metabolism was not known and the data about assimilation are questionable. The tentative equations are:

Ribose-grown organisms :

$10 \cdot 0$ ribose $+20 \cdot 1 \mathrm{O}_{2} \rightarrow 20 \cdot 7 \mathrm{CO}_{2}+6 \cdot 2$ acetic acid $+8 \cdot 7 \mathrm{C}$ assimilated; carbon recovery $0 \cdot 84$.

Ribose-grown organisms with arsenite:

$10 \cdot 0$ ribose $+6 \cdot 3 \mathrm{O}_{2} \rightarrow 2 \cdot 3 \mathrm{CO}_{2}+6 \cdot 0$ acetic acid $+9 \cdot 1$ pyruvic acid $+0 \cdot 8$ acetylmethylcarbinol $+5 \cdot 5 \mathrm{C}$ assimilated; carbon recovery 1.01.

The results are summarized in Fig. 13.
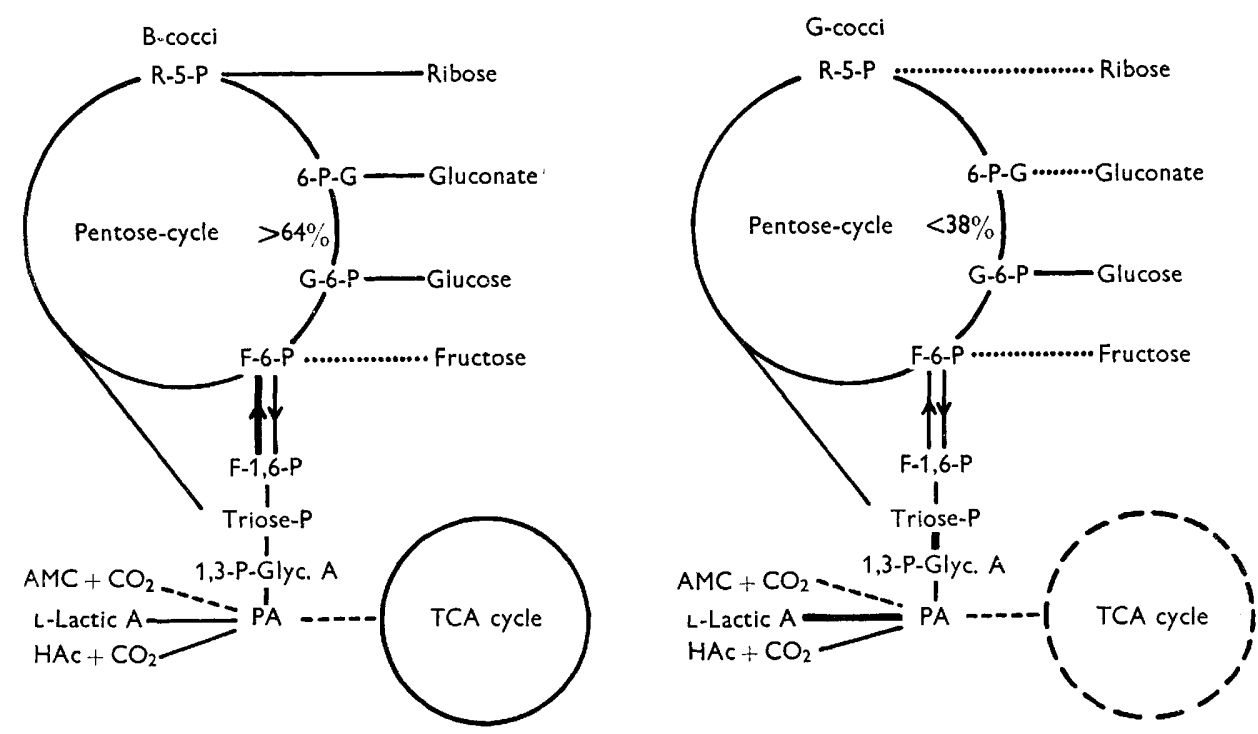

Fig. 13. Scheme of carbohydrate dissimilation by Staphylococcus aureus. - , Very active; -, active; ...., weakly active ; ......, absent. 
The excellent help of Miss W. van Thienen is gratefully acknowledged. Part of this work was made possible by the financial support of the Dutch Organization for Health Research.

\section{REFERENCES}

Aronoff, A. (1960). Techniques of Radiobiochemistry, 4th ed. Ames, Iowa: The Iowa State University Press.

Barker, J. B. \& Summerson, J. H. (1941). The colorimetric determination of lactic acid in biological material. J. biol. Chem. 138, 535 .

Bosch, L. (1955). Biochemische en endocrinologische onderzoekingen van normaal en neoplastisch weefsel. Doctoral thesis, Delft.

Chance, B. (1952). Spectra and reaction kinetics of respiratory pigments of homogenized and intact cells. Nature, Lond. 169, 215.

Collins, F. M. \& Lascelles, J. (1962). The effect of growth conditions on oxidative and dehydrogenase activity in Staphylococcus aureus. J. gen. Microbiol. 29, 531.

Colowick, S. P. \& Kalckar, H. M. (1943). The role of myokinase in transphosphorylations. I. The enzymatic phosphorylation of hexoses by adenyl pyrophosphate. $J$. biol. Chem. 148, 117.

Das, S. K. \& ChatterJee, G. C. (1962). Pyrithiamine adaptation of Staphylococcus aureus. I. Adaptation and carbohydrate utilization. J. Bact. 83, 125.

Dawes, E. A. \& Holms, W. H. (1958a). Metabolism of Sarcina lutea. I. Carbohydrate oxidation and terminal respiration. J. Bact. 75, 390.

Dawes, E. A. \& Holms, W. H. (1958b). Metabolism of Sarcina lutea. III. Endogenous metabolism. Biochim. biophys. Acta, 30, 278.

Dawes, E. A. \& Holms, W. H. (1958c). Metabolism of Sarcina lutea. II. Isotopic evaluation of the routes of glucose utilization. Biochim. biophys. Acta, 29, 82.

Elek, S. D. (1959). Staphylococcus pyogenes and its Relation to Disease, 7th ed. Edinburgh and London: E. and S. Livingstone Ltd.

Fiske, C. H. \& SubbaRow, Y. (1925). The colorimetric determination of phosphorus. J. biol. Chem. 66, 375.

Friedemann, T. E. \& Haugen, G. E. (1943). Pyruvic acid. II. The determination of keto acids in blood and urine. J. biol. Chem. 147, 415 .

Fusillo, M. H. \& Weiss, D. L. (1958). Intermediary metabolism of antibiotic-resistant and antibiotic-sensitive staphylococci. Antibiot. Chemother. 8, 21.

GALE, E. F. (1951). The assimilation of amino acids by bacteria. II. The relationship between accumulation of free glutamic acid and the formation of combined glutamic acid in Staphylococcus aureus. Biochem. J. 48, 290.

Gronlund, A. F. \& CaMpbell, J. J. R. (1961). Nitrogenous compounds as substrates for endogenous respiration in microorganisms. J. Bact. 81, 721.

Hamer, C. J. A. van den \& Elias, R. W. (1958). A method for the determination of D(-)-lactic acid. Biochim. biophys. Acta, 29, 556.

HAMER, C. J. A. VAN DEN (1960). De koolhydraatstofreisseling van melkzuurbacterien. Doctoral thesis, Utrecht.

HANcock, R. (1960a). The bactericidal action of streptomycin on Staphylococcus aureus and some accompanying biochemical changes. J. gen. Microbiol. 23, 179 .

HANCOCK, R. $(1960 b)$. The amino acid composition of the protein and cell-wall of Staphylococcus aureus. Biochim. biophys. Acta, 37, 42 .

Heath, H. C., Hurwitz, J., Horecker, B. L. \& Ginsburg, A. (1958). Pentose fermentation by Lactobacillus plantarum. J. biol. Chem. 231, 1009.

Jinsen, E. M., Altschuller, H. \& Bard, R. C. (1957). Glycolytic and respiratory enzymes of Trichophyton mentagrophytes. J. Bact. 74, 656.

Kulka, R. G. (1956). Colorimetric estimation of ketopentoses and ketohexoses. Biochem. $J .63,542$.

MeJBaum, W. (1939). Über die Bestimmung kleiner Pentosemengen insbesondere in Derivaten der Adenylsäure. Z. physiol. Chem. 258, 117. 
Neilands, J. B. (1955). Lactic dehydrogenase of heart muscle. In Methods in Enzymology, 1, 449. Ed. by S. P. Colowick and N. O. Kaplan. New York: Academic Press Inc.

Newburgh, R. W. \& Cheldelin, V. H. (1955). Oxidation of carbohydrate by the pea aphid Macrosiphum pisi (KLTB). J. biol. Chem. 214, 37.

RACKer, E. (1950). Spectrophotometric measurements of the enzymatic formation of fumaric and cis-aconitic acids. Biochim. biophys. Acta, 4, 211.

RAMSEY, H. H. (1962). Endogenous respiration of Staphylococcus aureus. J. Bact. 83, 507.

Rose, I. A., Grunberg-Manago, M., Korey, S. R. \& Ochoa, S. (1954). Enzymatic phosphorylation of acetate. J. biol. Chem. 211, 737 .

Schramm, M., Klybas, V. \& Racker, E. (1958). Phosphorylytic cleavage of fructose-6-P by fructose-6-P phosphoketolase from Acetobacter xylinum. J. biol. Chem. 233, 1283.

Sevag, M. A. \& Swart, E. A. (1947). Metabolism of pyruvic acid by bacteria. Arch. Biochem. 13, 401.

ShaNkaR, K. \& BARD, R. C. (1956). Effect of metallic ions on the growth, morphology and metabolism of Clostridium perfringens. J. Bact. 69, 436.

Sibley, J. A. \& Lehninger, A. L. (1949). Determination of aldolase in animal tissues. J. biol. Chem. 177, 859.

Siebert, G., Dubuc, J., Warner, R. C. \& Plaut, G. W. E. (1957). The preparation of isocitric dehydrogenase from mammalian heart. J. biol. Chem. 226, 965.

StJernholm, R. \& Wood, H. G. (1960). Trehalose and fructose as indicators of metabolism of labelled glucose by the propionic acid bacteria. J. biol. Chem. 235, 2753.

VANDEMark, P. J. \& Woon, W. A. (1956). The pathways of glucose dissimilation by Microbacterium lacticum. J. Bact. 71, 385.

Westerfeld, W. W. (1945). A colorimetric determination of blood acetoin. J. biol. Chem. $161,495$.

Woon, H. G. \& Katz, J. (1958). The distribution of carbon-14 in the hexose phosphates and the effect of recycling in the pentose cycle. J. biol. Chem. 233, 1279. 